\title{
The Dynamics of Taking Offense. Concluding Thoughts and Outlook
}

Birgit Meyer

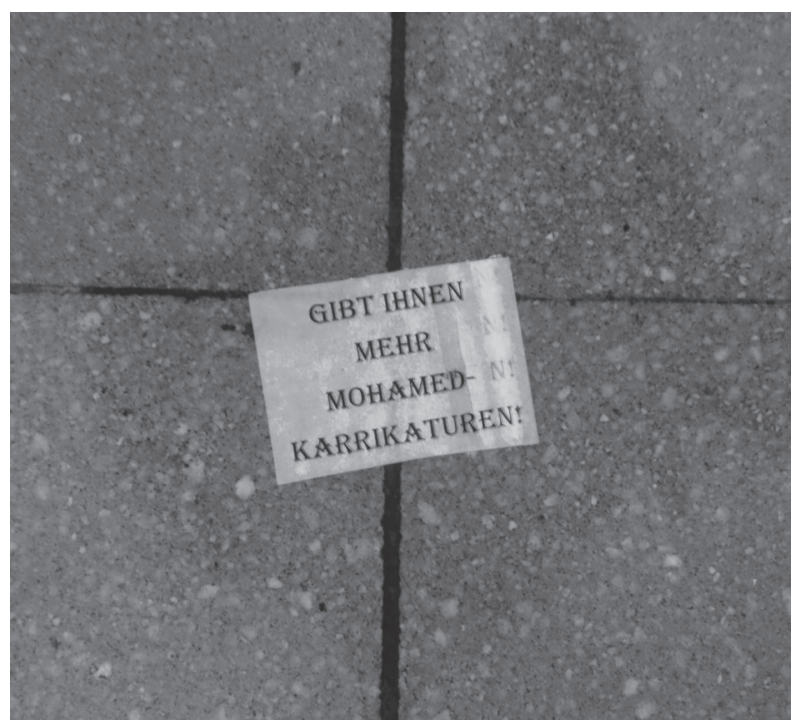

[FIG. 1]

Message placed on stairs

of Schöneberg train

station, Berlin 2016

(photo by Jojada Verrips)

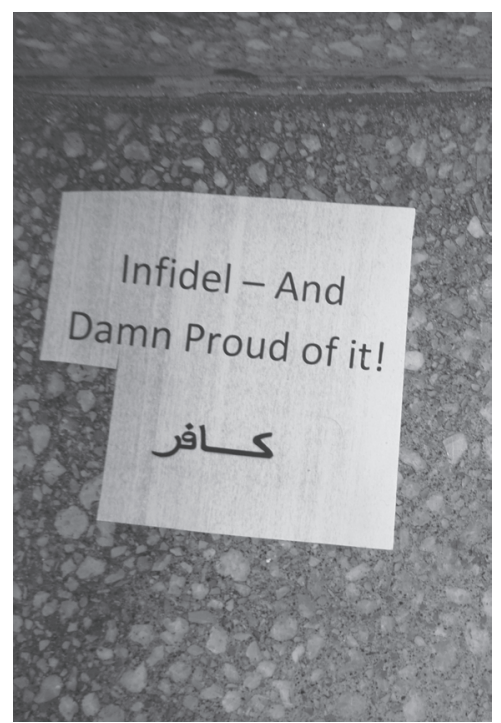

[FIG. 2]

Message placed on stairs

of Schöneberg train

station, Berlin 2016

(photo by Jojada Verrips) 
»Gibt ihnen mehr Mohamed-Karrikaturen!« - »Give them more Muhammad cartoons! « - was the message printed on small pieces of paper casually distributed on the stairs to Berlin's Schöneberg train station in February 2016 (Fig. I). They struck my eye in passing and evoked in my mind the so-called cartoon controversy and all that happened in its slipstream. Launched by a »proud infidel « of Arabic descent, as another piece of paper in the same style disclosed a bit later, the message takes a clear position in an ongoing, escalating, and at times violent struggle about the public presence and representation of Islam in Western societies in general and the use of cartoons mocking the prophet Muhammad in particular (Fig. 2). As a longstanding genre in northern European political culture, cartoons mock and ridicule people, groups and opinions especially those with some power. Cartoons that violate taboos and desacralize what is held sacred for a religious tradition - Christianity as well as Islam tend to generate heightened public attention. ${ }^{2}$ What does the fact that many Muslims perceive representations of the Prophet in publications like JyllandsPosten and the Charlie Hebdo magazine as offensive imply for freedom of expression in our ever more diverse European societies in which religion, against all expectations, is still remarkably present, albeit in new forms?

Notwithstanding two spelling mistakes, ${ }^{3}$ the message of the "proud infidel « is as clear as it is crude. It calls upon cartoonists, journalists, and the general public to provide Muslims with more unsolicited gifts (with gift-giving understood here as an aggressive act, in the sense of "give it to them«). Those who cannot stand such cartoons and ask them to be banned do not belong to Germany and Europe at large - as an earlier paper message stated: »Islam is as German/European as the burning of widows $\odot \otimes^{4}{ }^{4}$ The right to offend and the 
ability to relativize feelings of being offended are featured as central values of secular society; those who do not take part in this consensus are out.

The set of written messages distributed in the middle of Berlin testifies to the salience and urgency of the issue of offensive pictures in public debate, which, to be sure, also involves more nuanced positions than the one taken by the "proud infidel « and hard-core secularists, on the one hand, and angry Muslims on the other, and takes place in various arenas. Though not presented directly, the Muhammad cartoons are evoked in the minds of the passersby.

Given all the attention they've generated in numerous references, the cartoons certainly qualify as »strong images in the sense outlined by Christiane Kruse. Standing out and attracting attention in a flood of visual items that are habitually overlooked, they are effective and affective, triggering sensations of pleasure and disgust and generating both attraction and offense. The cartoons are potentially offensive to pious Muslims and exactly for this reason pleasing to secularist protagonists, who see them as icons of freedom of expression that must be displayed by all means. ${ }^{6}$ In turn, many Muslims take offense with this secularist stance and its eagerness to provoke - rather than with the cartoons per se. In June 2014, when we held the conference on which this volume is based, we thought about the Muhammad cartoons as one telling instance of offensive images among others. The commotion around them indicates widely different stances toward political culture and the use of cartoons, the valuation of religion, and the visual depiction of the sacred in our increasingly diverse, internally divided, and unequally heterogeneous societies. In the aftermath of the massacre at the Charlie Hebdo offices in Paris in January 20I5, the shootings in Copenhagen at an event called »Art, 
Blasphemy and Freedom of Expression« and outside the city's Great Synagogue in Feb. 20I5, these differences became ever more accentuated and the need to understand the stakes involved in the presence and representation of religion ever more pertinent.

Clearly, as asserted throughout this volume, offensiveness is not intrinsic to images as such, but becomes attached to them in complex configurations in which people are different and differ (but do not necessarily »agree to differ«). The concern of this volume is not an analysis of Muhammad cartoons and the debates and emotions generated by them in European societies per se. Set up more broadly, it explores the making and effects of »offensive images« at the interface of art, religion, and society from a global perspective. It is not confined to Muslim sensibilities, but also takes into account sensibilities about images on the part of protagonists of other religious traditions and of secular stances. Posing the question, »What makes images powerful?", the first chapter by Christiane Kruse explores the migration of visual forms from their habitats in art and religion into a broader visual culture in which they generate charges of being offensive. Chapters 2-9 are detailed case studies of specific instances of visual forms that generate offense. The last two chapters, by Jojada Verrips and Christoph Baumgartner, offer broader reflections on the emergence of a sense of offense and the implications for coexistence in diverse societies with different sensibilities. Taken together, these essays speak to current politics and aesthetics of cultural representation across the globe. They indicate that our increasingly interconnected and at the same time highly diversifying world is prone to generate a lot of offense through pictorial media. In this concluding essay, I would like to reflect on two broader issues - first, 
the relation between art and religion; and second, the emergence of a sense of offense - that cut across the chapters and are important for future research. I end with a short coda raising questions about the aesthetics and ethics of diversity. Since my main interest is in the nexus of religion and visual culture, my reading of the contributions will be partial and not do justice to the insights and materials offered by each of them.

\section{Art and religion}

The rise of art in early modernity entailed the reframing of cult images embedded in medieval religiosity as aesthetic artworks. ${ }^{7}$ Art and religion differentiated into relatively autonomous domains with independent institutions both safeguarded by the state and enjoying their own, at times conflicting, freedoms of expression. ${ }^{8}$ This differentiation was also transmitted to non-Western societies in the framework of colonial governance and reiterated in independent nationbuilding (see Juneja on India). ${ }^{9}$ The relation between art and religion as it unfolded since the Renaissance and the Reformation is complex. Certainly it cannot be captured by a modernist teleology according to which religion was bound to disappear in the course of modernization, while art emerged as its counterpoint and secular substitute. Art and religion have coexisted in various constellations, entailing more or less open synergies and tensions.

Norbert M. Schmitz conveys a good sense of artists' shifting stances toward religion in $20^{\text {th }}$-century Europe. Avant-garde surrealists such as Luis Buñuel and Salvador Dalí engaged in anti-Catholic heresy at a time when the Catholic 
Church was still a dominant institution in Spain. Violating taboos through artworks that offended Christian sensibilities and bourgeois morals, these and other artists brought about the freedom and autonomy of art. Blasphemy and sacrilege were valued positively, as means to further emancipation and liberation. From an avant-garde perspective, artworks were expected to break the yoke of religion and tradition. However, with the waning grip of Christianity on society, heresy became a mere gesture with limited effects. This is the context in which Pasolini launched his provocations of the leftist secular mainstream with its inbuilt aversion to religion. Pasolini's heresy in his film Il Vangelo Secondo Matteo, Schmitz argues, was that he took Catholic orthodoxy and its sacred imagery seriously (without embracing orthodoxy or some kind of esoteric mysticism). Pasolini's use of Catholic forms offended the bourgeois secular establishment, not Catholics themselves. His heresy was not directed against religion, but against a saturated secular stance that predictably offends religion over and over again, without a social need to do so and with limited societal effects.

Nika Spalinger also invokes this habitual anti-religious stance at the beginning of her essay as characteristic of the art world before 9/II, in which artists engaged with Christian religion from a »distanced, critical, ironic, or cynical perspective« (p. 57). This transformed with the rise of conflicts over the presence and representation of Islam in Western societies. She is interested in artists engaging with religion from a post-secular perspective. ${ }^{10}$ The point for them is not to embrace religion as believers, but to take it seriously as a factor in contemporary multicultural and diverse societies. Against this background, they seek to come up with new kinds of provocations. What I find particularly interesting about her examples of performance artists engaging with the man- 
ifestation of Islam in Swiss society is that a sense of being provoked on the part of the public cooled down once the projects were identified as mere art, rather than actual expressions of Islamic faith. As seen in the responses to Johannes Gees' project Salat, which involved an amplified call to prayer from church towers and hilltops, and Gianni Motti's Minarett built on the roof of Kunsthaus Langenthal show, many witnesses were prepared to accept the freedom of art even though they felt irritated by the Islamic content. At the same time, they sought to limit the freedom of religious expression for Muslims in everyday life (culminating in the interdiction of the building of minarets in 2009).

The preparedness to grant the domain of art a certain freedom to experiment, provoke, and blaspheme is subject to individual beholders' dispositions and societal arrangements. The contributions to this volume show intriguing differences in the public acceptability of the freedom of artistic expression, ranging from the Swiss context described by Spalinger, through the prohibition of the display of Serrano's Piss Christ and Chris Ofili's Holy Virgin Mary in the Us (Kruse), to the refusal to accept the idea of the autonomy of art in the case of Hindu protesters' opposition to the art of Maqbool Fida Husain in India (Juneja) and the repressive stance toward performance artists who indulge in drastically transgressive acts in China (Becker). Juneja's statement about the relation between the autonomy of art and public protest highlights an important point: »The idea of art's autonomy is in a sense also about its isolation. Attempting to overcome this by intervening in the public sphere or addressing the snation can also make art and artists more vulnerable« (p. I83). So it may well be that the more art becomes public and accessible, the more resistance and charges of blasphemy and sacrilege it provokes. ${ }^{\text {II }}$ In any case, the 
autonomy of art cannot be taken for granted in non-Western settings where the introduction of the category of art (in the Western, now universalized sense) is recent and its relation to local traditions of figuration and visual regimes is not yet fixed. Instead, as the papers by Juneja and Svašek show, the valuation of art as a category in society and the negotiation of the boundaries among religion, art, and heritage should be subjected to detailed research and comparison from a global perspective.

In the aftermath of $9 / \mathrm{II}$ and the cartoon controversies in Europe, the modernist teleology that predicted secularization and disenchantment as part and parcel of modernization was challenged. ${ }^{12}$ This yielded strong affirmations of artistic freedom of expression in the face of Islamist criticisms, ${ }^{13}$ but also induced more or less subtle forms of self-restraint and self-censorship on the part of artists, museums, and cultural entrepreneurs, especially with regard to issues related to Islam. ${ }^{\mathrm{I} 4}$ Long imagined to be a matter of past struggles between a repressive Christian morality and avant-gardist provocations, the manifestations of blasphemy and heresy disturbed »the idea of a progressive rationalization and privatization of religion« (Korte, p. II2). Religion became a big issue for the art world. A number of prominent exhibitions and catalogues emerged, including Iconoclash. Beyond the Image Wars in Science, Religion and Art (2002), IO० Artists See God (2004/05), Seeing God (2005/06), Medium Religion (2008), The Problem of God (2015/16), and Gott und die Welt (2016), ${ }^{15}$ which explored synergies and animosities between art and religion outside of hackneyed frameworks. ${ }^{16}$ David Morgan aptly states: 
Art and religion are different cultural forms, but they are historically tied to each other and analogous in many, but not all respects. They differ in that they address different target groups that have very different goals. And we should not lose sight of how differently they view pictures. Both go to great efforts to place high value on visual artifacts and to direct them by attaching a comprehensive toolbox to pictures. But the one lends an aura to the singular and unique, while the others aim to spread holiness, so that a copy entails no loss of aura, but rather a superabundance of it. The artwork and the devotional picture belong to different, though also parallel and often overlapping pictorial cultures, since they both devote themselves to producing and maintaining holy objects. ${ }^{17}$

Of great relevance to the rethinking of the relation between art and religion is the pictorial or iconic turn, which expanded the study of images beyond the modern framework of »art « to include audiovisual forms situated at the heart of everyday life. In the study of visual culture (in German: Bildwissenscbaft), scholars developed alternative approaches to images, asking about the "power « and »agency« of images and their affective impact on beholders (as Kruse points out). In this context, the cultic image embedded in a religious framework »before the era of $\operatorname{art} \ll^{18}{ }^{8}$ is approached as a resource for understanding the power of images in our time. ${ }^{19}$

Pondering the contributions to our volume in this light, I would like to draw out one aspect of the relation between religion and art, or more broadly audiovisual forms, that warrants further exploration. Examples like Ofili's The Holy Virgin Mary, the photograph of Conchita Wurst in his Jesus-look, the billboard with the »Merkel rhombus« discussed by Christiane Kruse, 
Madonna's crucifixion scene analyzed by Anne-Marie Korte, and offensive imagery introduced by Jojada Verrips show that (especially Catholic or medieval) Christianity offers a rich repository of figures and themes that are taken up by artists and producers of popular culture. The iconoclasms in the aftermath of the Reformation and the Protestant rejection of cult images notwithstanding, enduring imagery from the archive of Christianity is still around; ${ }^{2 \circ}$ it has an "afterlife« in the sense of Aby Warburg. As noted by Morgan in the quote above, artists usually take up Christian figures and themes for other purposes than religious devotion; they do not strive to enhance religious piety. Often the religious forms and motifs adopted by contemporary artists function independently from and undisturbed by institutionalized Christianity. A simple transposition of authorized religious imagery to art may easily be judged as an offense to good taste and found cheesy. ${ }^{21}$

In this context, it is interesting that representatives of Christian churches in Europe - especially Catholic churches - are embracing secular, contemporary art deliberately, emphasizing elective affinities between the ways artists and the religious faithful gesture toward the invisible or sublime, and opening their doors to art exhibitions. ${ }^{22}$ Such assertions of compatibility of Christianity and the modern art world frame Christianity as a vital part - or even as the cradle - of secular culture, in sharp distinction to Islam.

But, as this volume also shows, the transposition of religious tropes into artworks may generate charges of blasphemy, even though the artists themselves do not intend their works as a critique of religion. ${ }^{23}$ Artworks and performances that resemble conventional, authorized representations of the sacred and yet digress from them - e.g., by the use of unusual materials that are con- 
sidered polluting (elephant dung in The Holy Virgin Mary, urine in Serrano's Piss Cbrist), or the substitution of one element for another (e.g. Madonna instead of Jesus in a loincloth) - are prone to trigger a sense of offense, depending on the dispositions of the beholders. Such works contain an intrinsic iconoclash, understood by Kruse in the footsteps of Latour as »an ambivalence embedded in the picture that leads one viewer to see the painting [or any other artwork, BM] as sacred and the other as sacrilege (Kruse, p. 24) or perhaps even the same viewer sensing attraction and repulsion at the same time. ${ }^{24}$ They are in principle open to multiple interpretations and experiences. Korte's reading of Madonna's crucifixion scene is a case in point. While many Christians dismissed it as blasphemous and protested the show, Korte detects a resonance with so-called Christa sculptures and paintings that appropriate the crucifixion to take contemporary suffering and affliction as a theme - an instance of »iconoclash between sacred symbol and female corporeality and sexuality« (p. 132). Offering »an uncanny admixture of secular and religious values« (p. 132), the scene is a typical instance of a post-secular blurring of religion and popular culture.

The creative appropriation of Christian tropes in art and popular culture betrays a longstanding affinity between religion and images that survived despite the disentanglement and differentiation of religion and art into separate domains. Sigrid Weigel hits the nail on the head:

The fact that, with the gaze back to the picture before the era of art, pictures in religious and cultic contexts, in particular, have become relevant again for current picture theory, is true also for a grammatology of the pictures. This applies not only to the aforementioned almost sacral auratization 
of many pictorial worlds, it also includes acute upheavals in the public and political approach to pictures, which have in part taken on the form of a new iconoclastic controversy, if not a new war of pictures - for example in the dispute about the so-called Muhammad caricatures: a clash of cultures that is fought out as a struggle over pictures. Here, the understanding and assessment of pictures is still affected by traditional schisms whose culthistorical and picture-theological preconditions must be reflected upon. ${ }^{25}$

Indeed, in the face of a remarkable recycling and reproduction, via ever newer media, of iconographic traditions, pictorial genres, and attitudes toward images from the medieval past, it is high time for a joint effort on the part of scholars in art history, visual studies, and religious studies to come to grips with the continued use and appeal of religious imagery. Of course, art historians working on periods up to the Renaissance have paid ample attention to Christian traditions of figuration. But with the rise of art as a secular category, art historians working on art in modern society could seemingly afford to disregard religion. A great number of art historians working on contemporary art have been somewhat reluctant to take religion seriously, while scholars of religion had little affinity with the study of images. ${ }^{26} \mathrm{~A}$ systematic genealogy of the relation between religion and art - and their respective scholars - is still to be undertaken and would require detailed collaborative research on the part of scholars of religion and art history at the interdisciplinary interface of visual studies. ${ }^{27}$ Here, much can be gained by taking as a starting point genealogical work that traces how Catholic traditions of figuration and visual regimes shaped the making of 
images »before the era of art « and still inform how we look at images in our time. ${ }^{28}$ In my view, a post-secularist perspective that does not take modernist expectations about art and religion for granted and that resists a simplistic view of secularization in terms of a gradual reduction or even disappearance of religion is a productive starting point for grasping the stakes of current image wars (see also Spalinger, Korte).

But there is more. Besides revisiting the relation between art and Christian religion in Western societies from a genealogical perspective, it is important to research the differences between divergent religious visual regimes that involve authorized modes of figuration that shape whether and how the sacred is represented and depicted and practices of looking at and relating to religious (and other) images. New synergies should be developed between comparative religious studies, anthropology, and the study of visual culture. Islam, Hinduism, Christianity, and other religious traditions can be distinguished by their specific, often internally varied and contested visual regimes. ${ }^{29}$ Secular outlooks on the world also rest on embodied visual regimes with their own possibilities and restrictions. Visual regimes inform attitudes toward art and visual culture on the part of religious practitioners as well as non-religious persons. $3^{\circ} \mathrm{O}$ 'Meara argues that the Kaaba not only is regarded as the center and heart of the Islamic world, but also generates Muslims' outlook on the world (which is why the representation of the Kaaba is subject to certain restrictions). Juneja shows how »darsan « - »the exchange of vision between a deity and a worshipper at the heart of Hindu worship« (p. 179) - also informs ways of looking at art in a highly affective, iconophile manner (so much so that early colonial museums opted for signage stating »No touching, no praying«(p. I80)). In my recent book Sensational 
Movies, which explores the interface between popular cinema and Christianity in Ghana, I also point to the spillover of Christian-Pentecostal modes of looking into the sphere of cinema, with movies being framed as audio-visualizations of the religious revelations offered in Pentecostal sermons. ${ }^{3 \mathrm{I}}$ Invoking these examples, my point is that religion matters to the way people value and look at art and manifestations of popular culture. As I argued extensively in recent work, it makes sense to approach religion as a corporeal and sensational phenomenon that involves multiple material media - words, sounds, images, sculptures - in accessing the divine and rendering it present..$^{32}$ Certainly as European societies become ever more diversified, it is of utmost importance to know about the differences between various religious and secular visual regimes as they come to the fore in tensions and incompatibilities with regard to representations of what is considered sacred, such as the cartoon controversy. For me, this volume shows the merits of an intensive conversation among scholars from multidisciplinary backgrounds and with differing expertise on regions and religious traditions, so as to unpack the perceived offensiveness of visual representations in our time.

\section{Senses of offense}

There is a consensus among all contributors to this volume that images are not intrinsically offensive and that their offensiveness arises in the experience of certain beholders who attribute it to the image (while others may remain indifferent, like it and defend it, or take offense not with the image as such but 
with the intention of its producer to offend). Moreover, many potentially offensive images do not provoke protests, as they are not in the limelight of public attention in mainstream media. ${ }^{33}$ So why bother? Why, to invoke Monica Juneja, »are we forced to engage seriously with attributions that brand images as obscene, blasphemous, and as having the power to violate sentiments and sensibilities? (p. I6I) The point is that acknowledging human attribution does not make offense unreal. Posing the question »is there such a thing as an >offensive picture ? « Christoph Baumgartner introduces two helpful distinctions to trace how a sense of offense arises. One is the distinction between picture and image. Following William J.T. Mitchell and Hans Belting, he defines an image as the thing that is seen in the picture, while a picture is the material medium through which an image is made visible. Whether one decides to use these two words in this manner or not (most contributors in this volume do not, and more generally in the literature the term »image is also often used in the broad sense of a visual form that includes the dimensions of picture and image, as pointed out in the introduction), the distinction between an immaterial image stored in the mind and its materialization in pictorial media helps provide a clearer idea about processes of the reception of visual representations and taking offense. For the offense experienced refers in the first place to the image seen in the picture; even if the picture is destroyed, the image lingers on. The second distinction concerns offense. Baumgartner identifies levels of offense, ranging from direct affronts to the senses that trigger immediate disgust, to higher-level sensibilities that are »intrinsically related to and determined by a person's morality or religion and the beliefs, values, and ideals that are part of this« (P. 32I). 
While offenses related to the former - e.g. disgust evoked by bodily fluids »out of place« - tend to be regarded as »natural« and therefore as common to humans irrespective of cultural differences, offenses related to higher-level sensibilities may be difficult to apprehend by people with other beliefs, values, and ideals. ${ }^{34}$ This analytical distinction helps explain why certain pictorial representations are not experienced as generally disgusting. However, as Baumgartner points out, the distinction should not be taken too far, as in actual practice the two levels usually are not separated. The dependence on specific beliefs, values, and ideals does not make the offense less real for the person experiencing it. »Rather, the opposite is true, «Baumgartner states, for »if the relevant moral or religious principles, values, and norms are constitutive of the self-understanding of a person, she can be profoundly offended by violations of such principles, values, and so forth « (p.322). Based on Harry Frankfurt's theory of caring, according to which »a person who cares about something is, as it were, invested in it« (p. 33I), Baumgartner argues that humans become so deeply entangled with what they hold dear that they may feel compelled to react when they experience it as being violated. In this phenomenological sense, offensive pictures do exist, albeit not for everyone.

The point is that a sense of offense sticks with the medium that conveys the image and bounces back, making people act. They may feel pain and disgust, look away or more closely, explain why they are offended, take legal action and call for a ban, or attack the image or even its producers and distributors, to mention just a few possible responses. Paradoxically, an item that beholders qualify as offensive is offensive to them: some kind of switch occurs through which an object of vision starts to act upon its beholders. How can 
this switch be explained? I agree with Christiane Kruse that Mitchell's thesis »that the offending nature of images derives from a primitive belief in their aliveness seems too one-sided« (p. I8). The focus on the powers, wants, loves, and lives of pictures, as developed by Mitchell, certainly contributes to a better understanding of the way humans relate and respond to visual culture, but is of limited use to grasp the rise of a sense of offense. After all, different beholders may respond differently to images, with only a few feeling offended and many remaining indifferent (though possibly all the more touched by the qualification of a visual form as offensive, as is the case with non-Muslim, secular responses to the Muhammad cartoons). What exactly makes a visual form - both the image seen and its material carrier - offensive has to be explored in detail, inquiring into the specific ways in which religious and secular visual regimes govern stances toward the representation (and representability) of the sacred, as Baumgartner also argues. In contemporary plural societies, images become nodal points for the articulation of fundamental »ideological differences, whether these be religiously, politically, gender-thematically, artistically, or otherwise motivated (Kruse, p. 22). In other words, images are productive starting points for exploring the malaise of diversity and analyzing clashes between values, ideas, and sensibilities. In such clashes, the attribution of life to an image may be one possibility among others that accounts for the fact that people experience it as powerful and offensive.

While offensiveness is a matter of attribution, offense is nonetheless more likely to arise in connection with certain themes than with others. This is the thesis put forward by Jojada Verrips, who discerns »a limited number of genres (and subgenres) of imagery that repeatedly function as neuralgic 
points and sources of hot-headed, impetuous, and sometimes violent and iconoclastic reactions « (p.284). The realms of sexuality, the sacred, and death form an »eternal triangle of existential neuralgic points« (p. 289); transgressive representations with regard to this triangle inform sensibilities and underpin the emergence of scandals about offensive, inappropriate images. This triangle is »eternal« inasmuch as it refers to an anatomy of offense that underpins many commotions involving offense. Of course, the actual rise of charges of offense depends on specific, historically situated circumstances. To study how such scandals around offensive imagery actually come about, he takes a sociological perspective and introduces a second triangle. This triangle distinguishes among the producers, victims, and witnesses of offensive imagery, all of whom partake in the creation of a scandal around a work charged with being offensive. His thesis and overview serve as a reminder that the prominence in this volume and in contemporary public debate of charges of offense made from a religious standpoint should not make us forget that sensibilities to images deemed offensive also exist in a secular context. Scandals arising from Frémiet's sculpture of a gorilla carrying off a woman to current artworks experienced as »aesthetic terrorism « betray the ability of art to shock and transgress secular values - which, along with norms and sensibilities, change over time, in addition to the actual works to which people take offense. As noted before, shock and scandal have become widely accepted elements of artistic production, and a broader Western public is prepared to accept the autonomy of the domain of art. Still, it is telling that nowadays, exhibitions containing potentially shocking material often address visitors with a cautionary advisory. 
To understand the genesis of offense given by and objections to images charged withbeing offensive, it is a useful exercise to undertake some subjective introspection. Of all the »offensive images « presented and analyzed in this volume, the only ones I personally feel deeply uncomfortable about are the photographs in Tania Becker's chapter, especially the series on Zhu Yu's Eating People, which show the artist - whether this is real or staged does not matter eating a fetus, which I find almost unbearable to look at. Like many spectators in China and elsewhere, I feel disgusted. I do not want to see these photographs, which offend my sense of human life as an essential value, even though I realize through Becker's perceptive analysis that the artist wants to convey a critical message about dehumanization. I also have little appreciation for the sexist representations of the female body - » a stereotype of femaleness crudely: - presented in the essay by Jürgen Wasim Frembgen \& Asif Jehangir, against which pious Muslims in Pakistan position themselves (or, not present in this volume, for racist representations, Nazi symbols, and the like). Pondering these sentiments evoked by the visuals in this volume, I will also mention my unease with what I perceive as imagery intensely blasphemous toward Christianity, even though I long ago left behind the Calvinist faith of my youth. So it seems that the higher-level sensibilities once acquired in a religious framework are quite resilient. By contrast, I feel neutral about many of the images that trigger objections and protests on religious grounds, such as Husain's Saraswati, Ofili's The Holy Virgin Mary, Madonna on the cross, or a black cube by Apple or Gregor Schneider that remotely resembles the Kaaba. Of course, my own sensibilities indicate a particular habitus, developed through a typical middle-class socialization in the r960s and '70s in West Germany, 
which I share with many people of my generation. While I take my own embodied dispositions almost for granted, as an anthropologist I am aware that people socialized in a different manner within other religious traditions and cultural contexts do the same. Incorporated dispositions tend to be naturalized and frame how we see the world. As the secular sensibilities that have become mainstream in northern European societies are not shared by everyone, they cannot simply be taken as the default disposition of modern citizens (nor, I would add, should they be imposed). ${ }^{35}$ Scholars studying offensive images need to take as a starting point the fact that people sense and feel differently about images. This volume is intriguing and instructive because its contributions seek to unravel how and why people feel offended by images in various highly diverse settings in different parts of the world.

Of special importance in this endeavor is the idea of religion as not limited to doctrines and meanings, but as material and embodied. ${ }^{36}$ In my earlier work, I launched the notion of sensational form, through which believers achieve a sense of the presence of the divine via authorized images, words, songs, rituals, and other religious forms that generate religious sensations. ${ }^{37}$ From this perspective, religions can be distinguished by taking into account their distinct sensational profiles, through which believers learn to perceive, feel, and think about the divine. Jojada Verrips explains that negative responses to images, as is the case with Piss Christ and the The Holy Virgin Mary, which triggered strong reactions on the part of devout Christians, ${ }^{3}$ betray »a formidable mismatch between the kind of imagery that they learned to incorporate in their bodies as acceptable and imagery in the outside world that is at loggerheads with this embodied imagery and by which they are touched, "yielding "an unsettling collision 
at a deep corporeal level« (p. 3or). Similarly, as Juneja explains, Hindu beholders of Husain's Saraswati experience their engagement with deities via »darsan« as frustrated, since the goddess in the painting does not have a face and hence cannot look back. As Catholicism and Hinduism offer rich religious imagery, charges of blasphemy often arise because of a mismatch between the religious imagery incorporated by believers and other partly similar and partly divergent representations, as explained in the previous section. In contrast to these iconophile traditions, Sunni Islam holds strong reservations about the figural representation of God and of the Prophet Muhammad. ${ }^{39}$ For many pious Muslims, the cartoons are doubly offensive in that they not only depict Muhammad; they also mock him. Those who feel offended speak from a different "practice of visuality « $^{40}$ enshrined in the Islamic tradition that is not limited to issues of images per se, but involves a broader sensorial regime that shapes perception and sensation; hence the response to such visual forms as the cartoons. To get at the stakes of current »image wars «, it is necessary to understand how religions shape an embodied habitus that engenders particular sensibilities that may be irritated by particular appearances. On this basis, differences between religious traditions, as well as non-religious secular dispositions, become visible.

It is important to note that not all offense arises from an experienced clash between outward pictorial representations and internalized religious sensational forms. Another trigger is unauthorized appropriations. Simon O'Meara makes a compelling argument that the emergent feelings of offense in Muslims, triggered by a black cube built by Apple in New York, are not due to the presumed attempt to reproduce the Kaaba as such. Numerous copies of the Kaaba have existed across time up to the present. The point is rather that 
the unauthorized and decontextualized appropriation and replication of the form of the Kaaba is perceived as "matter out of place « in the sense of Mary Douglas. As pointed out above, the Kaaba generates »a world-organizing outlook« (p. 15I). Positing an analogy between dirt and offense, O’Meara argues that »offense arises when something does not fit within such an outlook; the Kaaba perceived as being taken as a shop, for example« (p. I5I). ${ }^{4 \mathrm{I}}$ Once it became clear that the similarity between the Kaaba and the Apple building was accidental and unintended, the initial irritation faded away. The case as such is instructive not only because it reveals the importance of the Kaaba in organizing a perspective on the world, but also because it shows that an emergent sensation of potential offense may easily fade away.

This is not so in the case of the Indian Muslim artist Husain, who was attacked for his allegedly blasphemous representation of the Hindu goddess Saraswati and the mythical figure Draupadi (Juneja) or in the case of the American religious studies scholar Wendy Doniger, who was charged with insulting Hindu gods in her book The Hindus. An Alternative History (Svašek). Members of right-wing groups in the Hindutva movement charged both Husain's paintings and Doniger's book with being blasphemous and called for the destruction of these works, taking particular offense at the emphasis placed on nudity and eroticism. Intriguing here is that the artist and the scholar took into account existing representations of nude deities and erotic postures in Hindu sculptures, paintings, and narratives. Trouble arose from their unauthorized appropriation by non-Hindu >outsiders<. In contrast to O’Meara’s example of the presumably illicit reproduction of the Kaaba, these two cases did not die down, but were taken to court and led to severe societal polarizations 
that fueled Hindutva's exclusivist identity politics. As Svašek points out in detail, the Indian Penal Code (section 295A) was mobilized to charge Doniger with violating the religious feelings of Hindus, even though she used existing Hindu imagery. Freedom of expression lost out to the primacy of religious sentiments that, ironically, appear to be inflected with $19^{\text {th }}$-century missionary sensibilities and a shameful stance toward eroticism that yielded a puritanized version of Hinduism. Hinduism is not simply featured as a religion, but as a cultural domain that informs citizens' sentiments - "pseudo-secularism《 indeed. Doniger's case also raises questions about the role of scholars in the representation of religion and culture. It shows that scholarly research may easily become part of public debate and criticism. Just as the autonomy of the domain of art is not taken for granted, independent scholarship does not stand by itself, safely ensconced in the university. How can responsible scholarship on potentially sensitive issues be conducted? Which strategy should be developed with regard to the publication of the offensive images we study in our texts? How far can publishers go in accommodating public sensibilities and avoiding controversy? Can one write about offense without being offensive?

\section{Coda: aesthetics and the ethics of diversity}

Exploring cases in which people are offended by artworks and other visual forms, this volume shows that the study of images is a perfect entry point into the clashes of different people's values, ideas, and sensibilities in pluralist settings. These values, ideas, and sensibilities are not merely individual and idiosyncratic - 
though of course they are lived by individuals - but also tied to particular religious traditions as well as non-religious stances. Pluralist settings consist of the coexistence of divergent $»$ communities of sense $«^{42}$ or »aesthetic formations. $«^{43}$ Coexistence amid difference does not imply an equality of difference, as diversity is »managed « through particular policies that echo the majority-minority configurations prevalent in a particular society. As we see in the case of India, there is a strong hegemony of a culturalized Hinduism from which Muslims are distinguished as Others who do not really belong to India. Similarly, Muslim migrants and post-migrants tend to be Othered in European societies, where the devoutly religious in particular are perceived as not fitting in with the secular prerogatives that underpin these societies (a sentiment that some of them also embrace). Of course, secularity does not imply the absence of religion, but rather a particular way of »managing « it - e.g., by safeguarding religious freedom. Still, the »return of religion« - or rather, if one looks more closely, the transformation and differentiation of religion into various manifestations - provokes secular sensibilities. It strikes a nerve especially among members of intellectual elites who pride themselves on having cast off the yoke of religion, with its repressive morals, in the aftermath of the 1968 student movements in Europe. This stance brings forth animosities toward both Islam and orthodox or evangelical Christianity that play into debates around offensive images, as this volume also shows. In my view, whatever one's personal stance toward religion, scholars must adopt a distanced, reflective attitude that analyzes clashes between religious and secular standpoints about images. In today's increasingly diversified societies with a strong presence of various religions, a secularist stance should not be taken as default, but subjected to detailed scrutiny. 
Since the 1990s, and more intensely after 9/II, religion and visual culture have become central topics of research in the social and cultural sciences. Their study prompts us to revisit neat, modernist narratives that postulated a move toward increasing rationalization and disenchantment, and the disappearance of religion, as key characteristics of modernity. This new attitude is expressed poignantly in Latour's statement $»$ We have never been modern $\ll^{44}$ and Mitchell's provocative question »What do pictures want? «The turn to the study of religion and images beyond the framework of art occurs in the context of a more general shift of focus from abstract concepts to practices, the body, and materiality as entry points for social-cultural analysis. In this context, the notion of aesthetics has been recaptured from its limitation to the sphere of the experience of art. Barely considered to have serious relevance for research and theory formation in the social and cultural sciences throughout much of the $2 \mathrm{O}^{\text {th }}$ century, aesthetics was recently rediscovered as relevant for understanding processes of identity formation in contemporary societies..$^{45}$

Some years ago I coined the notion »aesthetic formation« to accommodate the role of the body, the senses, and objects in inducing in people a sense of being part of a real, lived community. ${ }^{46}$ I used aesthetic in the broad Aristotelian sense of »aisthesis, " pointing to the sensory engagement with the world at large. ${ }^{47}$ The notion of aesthetic formation, I argued, is well suited for grasping the genesis of a divine presence for believers and hence the intensity of religious worldmaking. In my view, this notion proves helpful in undertaking a detailed analysis of the politico-aesthetic regimes of specific religious groups and traditions. However, given the coexistence of people in increasingly diverse societies, I am now thinking about how to expand this approach to the analysis of pluralistic 
settings constituted by coexisting groups with their respective realm of the senses and visual regimes. With its focus on clashes of different sensibilities to images, this volume is helpful for this intellectual endeavor, which will certainly preoccupy me for some years to come. ${ }^{48}$ Clashes over images are also clashes between - and about - aesthetic formations, whether they are grounded in religious or non-religious outlooks or not. In this context, the issue of what Jacques Rancière aptly calls »the distribution of the sensible, ${ }^{49}$ that is, the way in which senses and sensibilities are subject to hegemonic power, is of central relevance. Which politico-aesthetic regime is dominant in organizing the appearance of images, in various frameworks from art to popular culture and religion, and stipulates what can be represented, and how? What kind of responses does a dominant »distribution of the sensible « and its visual regime and practices of visuality evoke, and how does it handle divergent minority aesthetic formations? How do aesthetics held by opponents and defenders of certain images clash? To what degree do people develop what Brian Larkin aptly calls »techniques of inattention « and strategies of avoidance - for instance, not looking at certain images deemed offensive, deciding not to watch a program or visit an exhibition and when do they protest or take legal action? ${ }^{50}$ Or do they become numbed by or anesthetized toward certain, from their perspective, threatening stimuli against which they want to protect themselves in a much less conscious manner? ${ }^{\text {II }}$ And, on a more positive note, where can one discern overlaps and openings for an aesthetics shared across difference and welcoming otherness? ${ }^{52}$ The chapters in this volume offer a wealth of material to ponder these questions.

Human relations to images and visual presentations are not only a question of aesthetics, but also of ethics. Images enshrine moral values, while moral 
values also shape one's response to images. As we observed, a sense of offense often not only entails a sensation of disgust, but also mobilizes a rejection of the image(s) in question as dirty, obscene, and immoral (the case in the responses of devout Muslims toward popular movies in Pakistan, as analyzed by Frembgen). A closer investigation of the particular ethics enshrined in aesthetic formations and the ways these ethics clash or converge is an important topic for future research on images.

A serious consideration of the coexistence of different aesthetic formations that shape people's moral values and ways of looking at and being in the world gives rise to major questions about the overall configuration of the aesthetics and ethics of diverse societies. How can coexistence in these societies be organized? To what extent is mutual indifference a solution for coping with difference? How much acceptance of images experienced as offensive can reasonably be expected? How can we balance freedom of expression (in art, in journalism, on the Internet, in museums, in societal debate) and freedom of religion in today's highly sensitive - perhaps even hypersensitive societies, in which feelings have become central to the performance of citizenship and people are prone to feel hurt or offended? How can we develop a fair and reasonable distribution of sensitivity that lives up to the ideals of an open, democratic society? These questions will certainly be on the agenda of public debate and scholarly research for years to come. In any case, finding adequate answers will require great sensitivity on the part of scholars to understand the different aesthetics and ethics that inform struggles over images and other matters in diverse societies. 
1 I am deeply grateful to Christoph Baumgartner, Christiane Kruse, and Jojada Verrips for their perceptive and encouraging comments on an earlier version of this essay. Particular thanks to Christiane for introducing me to the complex world of art history and Bildwissenschaft.

2 Sigrid Weigel: Grammatologie der Bilder, Berlin 20I5, p. 233.

3 The correct German spelling would be: „Gebt ihnen mehr Moham(m)ed Karikaturen.«

4 »Der Islam ist so europäisch/deutsch wie die Witwenverbrennung $\odot . « I$ regard the use of the smiley symbol as indicating the propensity of the author to use irony. This indicator may well signal a difference from those who cannot laugh about the cartoons.

5 Jyllands-Posten published twelve cartoons on September 30, 2005 as a demonstration of free speech directed against selfcensorship regarding sensitive depictions Muslims might regard as offensive. See Weigel: Grammatologie (see note 2), p. $23^{8-242}$, for an analysis of the pictorial traditions evoked by the Danish cartoonists. There is a clear link with satirical representations in the post-Reformation religious wars and these contemporary cartoons. See also Finbarr Barry Flood: Inciting Modernity? Images, Alterities, and the Contexts of »Cartoon Wars«, in Patricia Spyer / Mary Steedly (eds.): Images That Move, Santa Fe 2013, Pp. 4I-72.

6 For a critique of the understanding of the secular as rational and critical (positioned in sharp contrast to religious fundamentalists regarded as irrational and unable to reflect critically) par excellence, see Saba Mahmood: Religious Reason and Secular Affect: an Incommensurable Divide? in Critical Inquiry 35/4 (2009), pp. 836-862; see also Talal Asad / Wendy Brown / Judith Butler / Saba Mahmood: Is Critique Secular? Blasphemy, Injury, and Free Speech. The Townsend Papers in the Humanities No. 2, Berkeley 2009 http://escholarship.org/uc/item/84q9c6ft\#page-5 (accessed on Feb. 4, 2017).

7 See Hans Belting: Likeness and Presence. A History of the Image Before the Era of Art, Chicago 1994.

${ }^{8}$ For a thoughtful publication addressing the limited engagement with religion in contemporary discourses on art, see James Elkins / David Morgan (eds.): Re-enchantment, New York 2009.

9 See also Maruška Svašek / Birgit Meyer (eds): Creativity in Transition. Politics and Aesthetics of Cultural Production Across the Globe, New York and Oxford 2016.

${ }^{10}$ See also Silvia Henke / Nika Spalinger / Isabel Zürcher (eds): Kunst und Religion im Zeitalter des Postsäkularen. Ein kri tischer Reader, Bielefeld 2012.

11 These terms partly overlap, in that they denote an inappropriate treatment - in the view of those mobilizing these terms - of what they take as sacred. While blasphemy refers to words and depictions deemed inappropriate, sacrilege refers to acts of desecration. The reason for the overlap lies in the fact that those who take offense with a particular verbal or pictorial representation regard it as actually affecting and desecrating what they hold sacred.

12 Thinking through this challenge has been one of the key concerns of recent scholarship in the study of religion. For a compelling multidisciplinary and multi-level analysis, see Hent de Vries (ed.): Religion: Beyond a Concept, New York 2008 .

${ }^{13}$ By contrast, as Anne-Marie Korte notes in her contribution, Christian charges of blasphemy that arose prominently, especially in the United States, received less attention. 
14 A famous example is the decision of the city administration of Venice not to grant Gregor Schneider permission to exhibit his work Cube Venice at the Piazza San Marco in 2005 because Muslims might take it as a copy of the Kaaba, though such concerns were not raised (see Simon O'Meara and Monica Juneja).

${ }^{15}$ For a list, see Alena Alexandrova: Nach Bildern, in Isabelle Malz (ed.): The Problem of God, Dusseldorf 20I5, p. 49.

${ }^{16}$ In recent years, museums have paid more attention to »religious « objects in their collections. For a prominent example, see: Treasures of Heaven. Saints, Relics and Devotion in Medieval Europe, British Museum 201 http://www.britishmuseum.org/whats_on/exhibitions/treasures_of_heaven. aspx (accessed on Feb. 4, 2017). See Crispin Paine: Religious Objects in Museums: Private Lives and Public Duties, London and New York 2013.

17 »Kunst und Religion sind unterschiedliche kulturelle Formen, die aber historisch miteinander verbunden und in vieler, aber nicht in jeder Hinsicht analog sind. Sie unterscheiden sich insofern, als sie verschiedene Zielgruppen mit sehr unterschiedlichen Zielen ansprechen. Und wir sollten nicht aus dem Blick verlieren, wie unterschiedlich sie Bilder betrachten. Beide geben sich große Mühe, visuelle Artefakte wertzuschätzen, den Betrachtern Hingabe zu entlocken, beim Erleben der Bilder Aura zu erzeugen und diese zu lenken, indem sie Bilder mit einem umfassenden Instrumentarium versehen. Doch die eine stattet das Singuläre, Einzigartige mit einer Aura aus, während es der Anderen darum geht, das Heilige zu verbreiten, sodass die Kopie keinen Verlust der Aura bedeutet, sondern vielmehr eine Überfülle davon. Das Kunstwerk und das Andachtsbild gehören jeweils zu verschiedenen, wenn auch parallel und häufig einander überschneidenden Bildkulturen, da sie sich beide der Herstellung und Aufrechterhaltung heiliger Objecte widmen.«David Morgan: Kunst und das
Andachtsbild: Visuelle Kulturen des Heiligen, in Isabelle Malz (ed.): The Problem of God, Dusseldorf 20I5, p. 63.

${ }^{18}$ Belting: Likeness and Presence (see note 7).

19 Scholars advocating the pictorial or iconic turn took up concepts pertaining to images in the sphere of religion, such as »idol«, »totem«, »fetish«, and »icon«. See e.g. William J. T. Mitchell: What do Pictures Want? The Loves and Lives of Images, Chicago 2005, pp. I88-196, on totem, idol, and fetish; Hans Belting: Iconic Presence. Images in Religious Traditions, in Material Religion I2/2 (2016), pp. 235-237, on the notion of the icon. For a recent historicizing analysis of contemporary visual culture in the light of the »afterlife of pre-modern understandings of and struggles over religious images, see Weigel: Grammatologie (see note 2).

${ }^{20}$ See Aaron Rosen: Art + Religion in the 2ist Century, London 2015. Acknowledging animosities between art and religion, Rosen calls attention to contemporary artists who »engage seriously with religious traditions, themes and institutions «. He argues: "As a new millennium begins to find its legs, it is time we set aside old assumptions about the antagonism between art and religion and look at the topic with fresh eyes. When we do so we discover a tremendous potential for reciprocity.«(p. 17). His point is not to question the distinction between art and religion per se, but to explore positive adoptions of religious imagery by artists that may easily be overlooked in light of current debates about blasphemy, for example about Serrano's Piss Christ, Ofili’s Holy Virgin Mary, or Maurizo Cattelan's La Nona Hora, showing Pope John Paul II struck down by a meteorite. The book offers many examples of artworks inspired by various religious traditions.

21 Overall, a secular perspective assigns low artistic value to religious art, i.e., artworks produced as part of devotional practice, for instance Warner Sallman's Head of Christ 
(1940), or does not regard it as art at all. See David Morgan: Warner Sallman and the Visual Culture of American Protestantism, in Morgan, David (ed.): Icons of American Protestantism: The Art of Warner Sallman, New Haven 1996, pp. 25-60; David Morgan: Visual Piety: A History and Theory of Popular Religious Images, Berkeley 1998.

22 The exhibition The Problem of God, for instance, was organized at the invitation of the Deutsche Bischofskonferenz to celebrate the 5oth anniversary of the Second Vatican Council to indicate »eine stärkere Öffnung des Kirche zur Gesellschaft und damit auch der Kunst«; see Isabelle Malz: The Problem of God (see note 17), p. 6. See also Oliphant's evocative exploration of an art project titled Suite Grünewald, in which the French Catholic Church offered a space for contemporary artists to reflect on Mathias Grünwald's Isenbeimer Altar (1512-1516). She sees this project as part and parcel of the culturalization of Catholicism, through which it becomes perfectly compatible with - and even a cradle of the French form of secularism (laicité); Elyane Oliphant: Beyond Blasphemy or Devotion. Art, the Secular, and Catholicism in Paris, in Journal of the Royal Anthropological Institute 21/2 (2015), Pp. 352-373.

${ }^{23}$ See Rosen: Art + Religion (see note 20), p. 15-16, who argues that Serrano's and Ofili's despised artworks stand closer to Catholic devotion and conventions of representing the sacred than do their religious critics, who dismiss these artworks as blasphemous, might realize. Of course, such an explanation cannot and should not serve to overrule the existence of hurt feelings.

${ }^{24}$ On the simultaneity of pleasure and disgust, see Carolyn Korsmeyer: Savoring Disgust. The Foul and the Fair in Aesthetics, Oxford 2orr. See also Jojada Verrips in this volume.

25 „Die Tatsache, dass mit dem Blick zurück auf das Bild vor dem Zeitalter der Kunst insbesondere auch Bilder in religiösen und kultische Zusammenhängen wieder für die gegenwärtige Bildtheorie relevant geworden sind, gilt auch für eine Grammatologie der Bilder. Das betrifft nicht nur die genannte nahezu sakrale Auratisierung vieler Bildwelten, es schließt auch akute Verwerfungen im öffentlichen und politischen Umgang mit Bildern ein, die teilweise die Gestalt eines neuen Bilderstreits, wenn nicht Bilderkriegs angenommen haben - wie etwa im Streit um die sogenannten Mohammed-Karikaturen: ein sclash of cultures‘, der als Kampf um Bilder ausgetragen wird. Darin wirken tradierte Schismen in der Auffassung und Bewertung von Bildern fort, deren kultgeschichtliche und bildtheologische Voraussetzungen reflektiert werden müssen.« Weigel: Grammatologie (see note 2), p. 19.

${ }^{26}$ As pointed out in my earlier work, the relative neglect of religious images and sculptures as compared with words and texts is one of the symptoms of the post-Enlightenment Protestant framework that has long structured knowledge production in the study of religion. In the aftermath of the Reformation, scholars of religion tended to neglect images as serious objects of study and privileged text as the prime medium of religion, while art historians were not inclined to take modern religion into account. See Birgit Meyer: Mediating Absence - Effecting Spiritual Presence. Pictures and the Christian Imagination, in Social Research: An International Quarterly 78/4 (20II), pp. I029-1056; id.: Picturing the Invisible. Visual Culture and the Study of Religion, in Method and Theory in the Study of Religion, 27 (2015), pp. 333-360. Working at the interface of religious studies and art history, David Morgan played a central role in profiling the study of religious visual culture, e. $\mathrm{g}$ The Sacred Gaze. Religious Visual Culture in Theory and Practice, Berkeley 2005; id.: The Forge of Vision: A Visual History of Modern Christianity, Berkeley 2015. See also the recent, groundbreaking initiative by Sally Promey to found the Center for the Study of Material and Visual Cultures of Religion: http://mavcor.yale.edu (accessed on Feb. 4, 20I7). 
${ }^{27}$ See Maria Micheale Luiselli / Jürgen Mohn / Stephanie Gripentrog (eds.): Kult und Bild. Die bildliche Dimension des Kultes im Alten Orient, in der Antike und in der Neuzeit, Würzburg 2013. See especially the general reflection on the relation between religion and art in the chapter by Jürgen Mohn: Von den Kult-Bildernzum Bilder-Kult »romantischer Kunstreligion. Religionsgeschichtliche Interpretationen zu Philipp Otto Runges Zeiten-Zyclus in religionsaisthetischer Perspektive, ibid., pp. 203-242.

${ }^{28}$ Hans Belting: Likeness and Presence (see note 7) offers a close reading of the icon and the struggle over its devotional use. Christiane Kruse: Wozu Menschen malen. Historische Begründungen eines Bildmediums, Munich 2003, explores the relation between image making and world making by taking into account ideas and debates at the interface of theology and art in medieval and early modern times.

${ }^{29}$ Along with this book project on offensive images, I am also involved, with Terje Stordalen, in editing a volume on the Figuration and Sensation of the Divine in Abrahamic Traditions, which explores the attitudes toward pictorial representation in Christianity, Judaism, and Islam. One of the central aims is to explore aesthetic practices in representing the divine, and the world at large, from a critical perspective that rejects the presumed aniconism of these traditions.

${ }^{30}$ For an insightful analysis of clashes around the Muhammad cartoons in Indonesia from divergent perspectives that rest on different »semiotic ideologies « that stipulate the value and status of images, see Webb Keane: Freedom and Blasphemy. On Indonesian Press Bans and Danish Cartoons, in Public Culture 21/1, pp. 47-77. He shows that a Western take on cartoons, as displayed by many secular defenders, is based on a semiotic ideology according to which images are mere vehicles of ideas and meanings and the press a site of free speech. By contrast, an experience of images as offensive does not regard them primarily in referential terms, but as an actual presence.
31 Birgit Meyer: Sensational Movies. Video, Vision and Christianity in Ghana, Berkeley 2015.

32 Birgit Meyer: Picturing the Invisible (see note 26); id.: Mediation and the Genesis of Presence, with a response to comments by Hans Belting, Pamela Klassen, Chris Pinney, Monique Scheer, in Religion \& Society. Advances in Research 5 (2014), pp. 205-254; see also David Morgan: The Sacred Gaze. Religious Visual Culture in Theory and Practice, Berkeley 2005; and Sally Promey: Sensational Religion. Sensory Cultures in Material Practice, New Haven 2014.

33 The Internet is a huge repository of images likely to evoke a sense of offense. Though they are publicly accessible (just a click away, so to speak), they rarely stir debate. It seems that charges of blasphemy and of being hurt are more likely to arise when images are presented in newspapers, books, and cinema. At the same time, the Internet plays a key role in globalizing such charges, as the Muhammad cartoon affair showed.

${ }^{34}$ The distinction resonates with the old nature-nurture debate in anthropology, which is problematic because it presumes an all too neat distinction between what is regarded as natural and what is regarded as cultural.

35 This is one of the central points of the book by Talal Asad / Wendy Brown / Judith Butler / Saba Mahmood: Is Critique Secular? (see note 6).

${ }^{36}$ Furthering research in this direction is the central concern of the journal Material Religion, which I am co-editing with David Morgan, Brent Plate, and Crispin Paine. See Birgit Meyer / David Morgan / Crispin Paine / S. Brent Plate: Material Religion's First Decade, in Material Religion Io/I (2015), Pp. 105-III.

37 Birgit Meyer: Religious Sensations. Why Media, Aesthetics and Power Matter in the Study of Contemporary Religion. 
Inaugural Lecture, Vrije Universiteit, Amsterdam, 6 October 2006; id.: Mediation and the Genesis of Presence (see note 32).

${ }^{38}$ See also Jojada Verrips: Offending Art and the Sense of Touch, in Material Religion 4/2 (2008), pp. 217-218.

39 Nonetheless, iconic representations of Muhammad were created in the Islamic world, with his face sometimes (but not always) »veiled, obscured by light, or, more rarely, inscribed with a type of grid that evokes his variant names, denotations of specific qualities«. This calligraphic representation evokes a mental image of the Prophet; Finbarr Barry Flood: Inciting Modernity (see note 5), p. 48. See also Christiane Gruber: Prophetic Products. Muhammad in Contemporary Iranian Visual Culture, in Material Religion I2/3 (2016), pp. 259-293.

${ }^{40}$ Frank Peter/Sarah Dornhof / Elena Arigitta: Introduction. Islam and the Politics of Culture in Europe, in Frank Peter/ Sarah Dornhof / Elena Arigitta (eds.): Islam and the Politics of Culture in Europe, Bielefeld 2013, p.r7. See also Mahmood: Religious Reason and Secular Affect (see note 6).

${ }^{41}$ Irritation about religious images being represented outside of their proper place may occur in many contexts. In his research on the conversion of a Catholic church into a worldly dance studio in Amsterdam, Daan Beekers reports that Church authorities were not prepared to leave Catholic material forms, including a mosaic depicting Jesus and Mary, to the new non-religious users of the building. From their perspective, such forms would be out of place in a worldly setting. Daan Beekers: Sacred Residue, in Susanne Lanwerd (ed.): The Urban Sacred. Städtisch-religiöse Arrangements in Amsterdam, Berlin and London. How Religion Makes and Takes Place in Amsterdam, Berlin and London, Berlin 20I5, Pp. 39-4I.

42 Beth Hinderliter et al.: Communities of Sense. Rethinking aesthetics and politics, Durham 2009.
43 Birgit Meyer: Introduction. From Imagined Communities to Aesthetic Formations. Religious Mediations, Sensational Forms and Styles of Binding, in Birgit Meyer (ed.): Aesthetic Formations. Media, Religion, and the Senses, Basingstoke 2009

${ }^{44}$ Bruno Latour: We Have Never Been Modern, Cambridge/ Mass. 1993.

45 See, for example, Andreas Reckwitz: Affective Spaces. A Praxeological Outlook, in Rethinking History 16/2 (2012), pp. $24 \mathrm{I}-258$.

${ }^{46}$ Birgit Meyer: Aesthetic Formations (see note 43).

47 Birgit Meyer / Jojada Verrips: Aesthetics, in David Morgan (ed.): Key Words in Religion, Media, Culture, London and New York, pp. 20-30. See also Bd 35 / 1,2 (2006) Jojada Verrips: Aisthesis and An-aesthesia, in Ethnologia Europea $35^{1 / 2}$, pp $27-33$

${ }^{48}$ I have just started a new collaborative research program, titled Religious Matters in an Entangled World. Things, Food, Bodies and Texts as Entry Points to the Material Study of Religion in Plural Settings, at Utrecht University that will run over a period of eight years (2016-2024).

49 Jacques Rancière: The Politics of Aesthetics. The Distribution of the Sensible, London 2006

${ }^{50}$ Brian Larkin: Techniques of Inattention. The Mediality of Loudspeakers in Nigeria, in Anthropological Quarterly 87/4 (2014), pp. 989-1015.

51 Susan Buck-Morss: Aesthetics and Anaesthetics: Walter Benjamin's Artwork Essay Reconsidered, in October 26 (1992), pp. 3-4I. See also Jojada Verrips: Aisthesis \& An-Aesthesia (see note 47). 
${ }^{2}$ See Rosi Braidotti: Conclusion. The Residual Spirituality in Critical Theory. A Case for Affirmative Postsecular Politics, in: Rosi Braidotti / Bolette Blagaard / Tobijn De Graauw / Eva Midden (eds.): Transformations of Religion and the Public Sphere. Postsecular Publics, New York 2015, pp. 249-272. 